\title{
Study of the Antifungal Effect of Essential Oils Extracted from Medicinal Plants of Algerian Northern Sahara: Pituranthos Chloranthus
}

\author{
Mehani M*, Segni L, Terzi V, Morcia C and Mehani I \\ Department of Biology, Gardaia University, Algeria
}

*Corresponding author: Mouna Mehani, Department of Biology, Gardaia University, Algeria, Email: mounameh@gmail.com

\section{Review Article}

Volume 3 Issue 2

Received Date: May 16, 2020

Published Date: July 01, 2020

DOI: $10.23880 /$ oajmms-16000124

\section{Abstract}

Humans use plants for thousands of years to treat various ailments, in many developing countries; much of the population relies on traditional doctors and their collections of medicinal plants to cure them. Essential oils have many therapeutic properties. In herbal medicine, they are used for their antiseptic properties against infectious diseases of fungal origin, against dermatophytes, those of bacterial origin.

The aim of our study is to determine the antifungal effect of essential oils of Pituranthos chloranthus on some pathogenic fungi. It is a medicinal plant used in traditional therapy. Essential oils have many therapeutic properties. In herbal medicine, they are used for their antiseptic properties against infectious diseases of fungal origin, against dermatophytes, those of bacterial origin. The test adopted, is based on the diffusion method on solid medium (Antibiogram), this method allows to determine the susceptibility or resistance of an organism according to the sample studied.

Our study reveals that the essential oil of the plants Pituranthos chloranthus have a different effect on the resistance of germs.

Keywords: Essential oil; fungal; Antibiogram; Pituranthos Chloranthus

\section{Introduction}

A large number of plants (aromatic, medicinal plants, spices and others) have very interesting biological properties that are different fields of applications, namely medicine, pharmacy, cosmetics and agriculture [1].

Throughout history, the plant kingdom has provided the essential human resources to its feeding, hygiene and health. Since ancient times, the fragrances of these same plants are associated with mystic rites, artistic and aesthetic.

For this, the return to nature has become indispensable and it must follow certain conditions for its use in the wide world of anti-infective, which expands from one day to another with the most powerful substances, more toxic and more expensive. The main requirement for this revival is a rigorous and rational scientific study of the antimicrobial activity of various natural extracts.

The bacteria belonging to the wide range of microorganisms also include viruses, fungi and parasites. Bacterial pathogens for humans are at the origin of many infectious diseases [2].

The antibiotics consider the almost universal solution 


\section{Open Access Journal of Mycology \& Mycological Sciences}

to serious infections, but drug efficacy is decreases. Bacteria and viruses have gradually adapted to resist medications and their increasingly [3].

The MAP are plants that have grown or have picks in his natural environment for its medicinal and had an infinite variety of jobs, to report the therapeutic area, food, cosmetics, industrial, etc.. Herbs can play an important role in conserving biodiversity. These plants are actually very familiar to rural people who are very sensitive to their scarcity and their disappearance. Indeed, medicinal plants play an important role of health care population and represent a significant source of income for many families in the countryside and cities [4].

Our research aims to study the biological activity of extracts of medicinal and aromatic plants (Pituranthos chloranthus) chosen for therapeutic characteristics in traditional medicine

\section{Work Methodology}

\section{Plant Material}

The plant material consists of the aerial parts of plants Pituranthos chloranthus of the Ghardaia region, harvesting of Pituranthos chloranthus was conducted in the month of December 2017 in the region of Mansora wilaya of Ghardaia.

\section{Pituranthos chloranthus}

Pituranthos chloranthusis widely known as one of the medicinal herbs with the highest antioxidant activity; Essential oils are a folk medicine and recently their use has expanded worldwide to include therapy against various kinds of inflammatory diseases. A great number of new drugs discovered in the last few decades are originate from natural sources [5]. Natural products have been increasingly used for the prevention and treatment of various conditions $[6,7]$. Pituranthos chloranthus essential oil has historically been used in the treatment of dysentery, hemorrhoids, inflammation, heavy menstrual flows and even cancer [8]. The French medicinal community currently treats diabetes, diarrhoea, gallbladder problems, gastric ulcers, liver problems, sterility and urinary stones with this oil $[9,10]$.

\section{Extraction of Essential Oils by Hydrodistillation}

The hydrodistillation of Pituranthos chloranthus (leaves dry) is performed using a Clevenger-type device (1928) [11]. The setup used is shown in Figure 1.

The extraction procedure comes down to boil a quantity of $100 \mathrm{~g}$ of dry plant for $2 \mathrm{~h}$ with water in a 1liter flask (Figure
1). The distillation was carried out with a recycling cohobage commonly known as described in the Ph Eur [12].

The essential oil yield was determined from fresh plant material [13], are defined as follows:

RHE $\mathrm{a}=\mathrm{HE}$ mass/Mass dry plant material

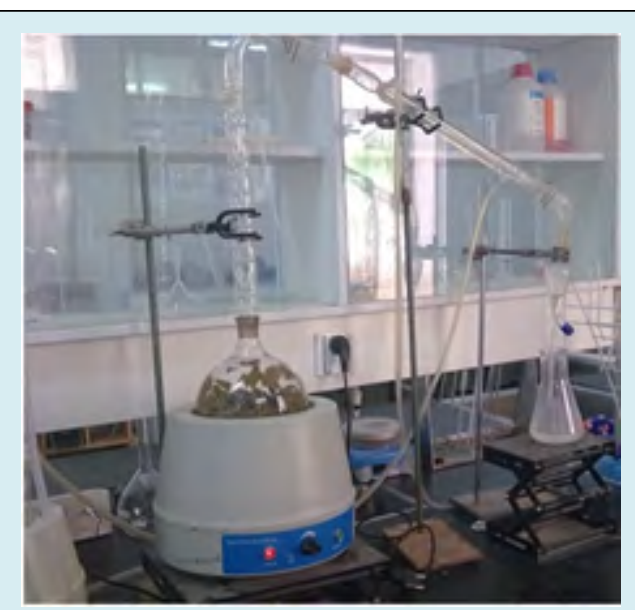

Figure 1: Installation of hydrodistillation (Clevenger Apparatus) [11].

\section{Study of the Antifungal Activity of Essential Oil}

For the realization of the antifungal activity was adopted method of direct contact. To prepare the different concentrations were taken different concentrations of essential oil of Pituranthos chloranthus $(50,10,5,2.5,1.25 \mathrm{mul})$ and adjust to $20 \mathrm{ml}$ PDA then stirred for 5minutes to homogenize the medium PDA with essential oil $[14,15]$.

\section{Results and Discussion}

\section{Antifungal Activity of Pituranthos Chloranthus}

Antifungal activity is revealed by the absence or presence of mycelial growth. The results of antifungal activity diameter of the essential oil of medicinal plants that are Pituranthos chloranthus are presented in the following graphs; Graphs $\mathrm{N}^{\circ} 2$ show mycelial growth ( $\mathrm{mm}$ ) of Fusarium sporotrichioides according to incubation time and the concentration of essential oil of Pituranthos chloranthus (Figure 2).

With different concentrations of essential oil extracted from Pituranthos chloranthus, we observe that mycelial growth of Fusarium sporotrichioides is remarkable after 72hours for the control and different concentrations of essential oil of Pituranthos chloranthus namely $0.0125,0.025$ and $0,05 \mu \mathrm{l}[16]$. 


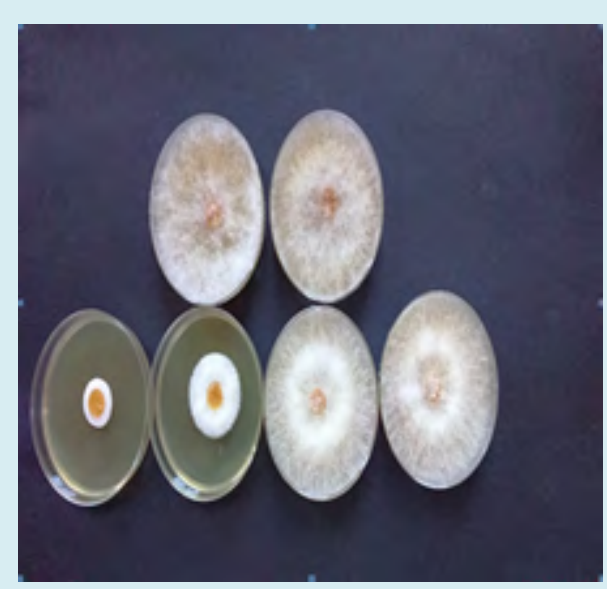

Figure 2: Antifungal Activity of Fusarium sporotrichioides of Pituranthos chloranthus.

\section{Antifungal Activity of Fusarium Graminearum in Pituranthos Chloranthus}

According to the graph N3 which represent the antifonguique activity of Fusarium graminearum depending on the incubation time and the concentration of essential oil of Pituranthos chloranthus one notices that there is an increase of mycelial growth with the incubation time with the exception concentration $0.025 \mathrm{mu} 1 / 20 \mathrm{ml}$ of PDA that it presents no mycelial growth of Fusarium graminearum (Figure 3) [17].

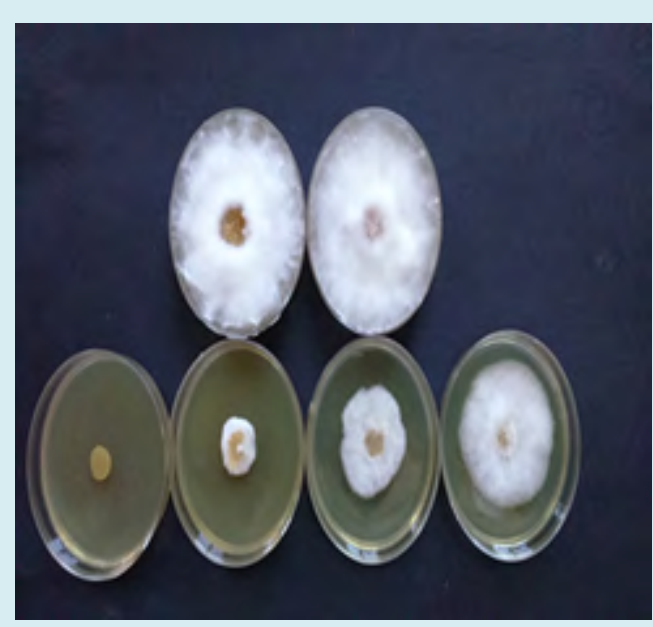

Figure 3: Antifungal Activity of graminearum of Pituranthos chloranthus.

Antifungal Activity of Fusarium Langsethiae in Pituranthos Chloranthus

With different concentrations of essential oil extracted from Pituranthos chloranthus, we observe that mycelial growth is remarkable after 72 hours for the control and the different essential oil concentrations in two plants 00062 and $0.0125 \mu \mathrm{l}$ by cons 0.025 and $0.05 \mu \mathrm{l}$ we observed no mycelial growth of Fusarium langsethiae in Pituranthos chloranthus (Figure 4) [18,19].

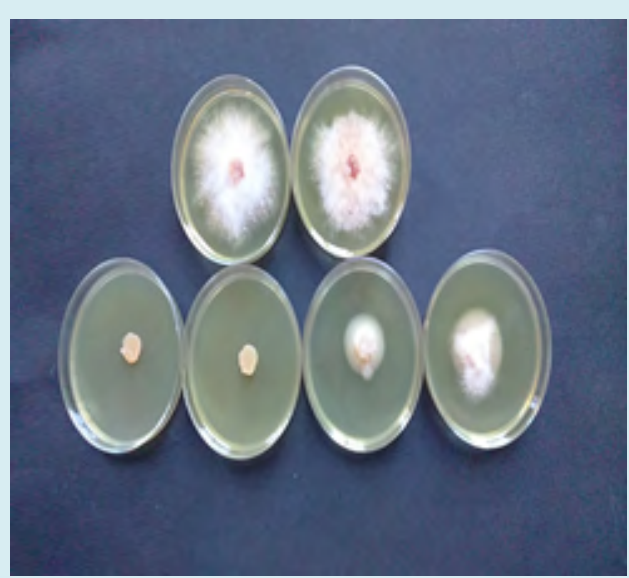

Figure 4: Antifungal Activity of Fusarium langsethiae of Pituranthos chloranthus.

\section{Conclusion}

All of these results are only a first step in the search of substance biologically active natural source. Additional tests are required and must be able to confirm the performance highlighted, for it would be interesting also to further phytochemical and biological investigations on these plants including the purification of the extracts obtained in order to isolate the molecules responsible for the antifungal activities, which will expand the therapeutic arsenal of herbal plants [20-22]. In Focus, for improved further research active molecules spontaneous plants of this study, it is desirable to: Protect plants against the disappearance.

The use of volatile formulations of aromatic and medicinal plants can have many advantages over existing products syntheses. Substances of vegetable origin are valuable sources of active material. These products of natural origin can play a very important role in control programs against fungi in the future. This study once again allows the development of the operation of the essential oil in the fields, pharmaceutical and cosmetics and as a preservative in the field of food industry. These preliminary results may be supplemented by other more detailed study (antioxidant is testing, performance testing on other bacterial strains, etc.).

\section{Acknowledgment}

Authors Could Never Accomplish This Task Without 


\section{Open Access Journal of Mycology \& Mycological Sciences}

The Help of So Many Generous People. Authors would like to Acknowledge My Professor at University of Ouargla. Ladjel Segni, Prf Terzi Valeria and Morcia Caterina For their Advices, Instruction, Assistance, Patience and Many Hours at Important Edits, Re-Writes, Analysis, and Discussions; without their Example I Would not be where I am today.

\section{References}

1. Ahmed G, El Ela AAA, Jakupovic M, El-Din SJ, Sabri AA, N (1990) Photochemistry 29: 3661-3663.

2. Benjumea D, Abdala S, Hernandez Luis F, Perez Paz P, Herrera DM (2005) Diuretic activity of Artemisia thuscula, an endemic canary species. Journal of Ethnopharmacology 100(1-2): 205-209.

3. Darias V, Bravo L, Barquin E, Martin Herrera D, Fraile C (1986) Contribution to the ethnopharmacological study of the Canary Islands. Journal of Ethnopharmacology 15: 169-193.

4. Dhingra V, Rao KV, Narasu LM (2000) Current Status of Artemisinin and Its Derivatives as Antimalarial Drugs. Life Science 66(4): 279-300.

5. Newman DJ, Cragg GM (2007) Natural products as sources of new drugs over the last 25 years. J Nat Prod $70(3): 461-477$.

6. Thomas KJ, Nicholl JP, Coleman P (2001) Use and Expenditure on Complementary Medicine in England: A Population Based Survey. Complement Ther Med 9(1): 2-11.

7. Mainardi T, Kapoor S, Bielory L (2009) Complementary and alternative medicine: herbs, phytochemicals and vitamins and their immunologic effects. J Allergy Clin Immunol 123(2): 283-294.

8. Kang HY, Na SS, Kim YK (2010) Effects of oral care with essential oil on improvement in oral health status of hospice patients. J Korean Acad Nurs 40(4): 473-481.

9. Amabeoku GJM (2009) Antidiarrhoeal activity of Geranium incanum Burm. F (Geraniaceae) leaf aqueous extract in mice. J Ethnopharmacol 123(1): 190-193.

10. Elmann A, Mordechay S, Rindner M, Ravid U (2010) Antineuroinflammatory effects of geranium oil in microglial cells. Journal of Functional Foods 2(1): 17-22

11. Ribnicky DM, Poulev A, Watford M, Cefalu WT, Raskin I (2005) Antihyperglycemic Activity of Tarralin, an Ethanolic Extract of Artemisia Dracunculus L. Phytomedicine 13(8): 550-557.
12. Setzer WN, Vogler B, Schmidt JM, Leahy JG, Rives R (2004) Antimicrobial Activity of Artemisia Douglasiana Leaf Essential Oil. Fitoterapia 75(2): 192-200.

13. Tan RX, Zheng WF, Tang HQ (1998) Biologically Active Substances from the Genus Artemisia. Planta Med 64(4): 295-302.

14. El Massry KF, El Ghorab AH, Farouk A (2002) Antioxidant activity and volatile components of Egyptian Artemisia judaica L. Food Chemistry 79(3): 331-336.

15. Heywood VH, Humphries CJ (1977) Anthemideaesystematic reviews. In: Harborne JB, (Ed.), the Biology and Chemistry of the Compositae 2: 851-898.

16. Kim JH, Jeon SB, Son KH, Kim EH, Kang SK, et al. (2002) New sesquiterpene-monoterpene lactone, artemisolide, isolated from Artemisia argyi. Tetrahedron Letters 43(35): 6205-6208.

17. Kim KS, Lee S, Lee YS, Jung SH, Park Y, et al. (2003) Antioxidant Activities of the Extracts From the Herbs of Artemisia Apiacea. J Ethnopharmacol 85(1): 69-72.

18. Kordali S, Kotan R, Mavi A, Cakir A, Ala A, et al. (2005) Determination of the Chemical Composition and Antioxidant Activity of the Essential Oil of Artemisia Dracunculus and of the Antifungal and Antibacterial Activities of Turkish Artemisia Absinthium, A. Dracunculus, Artemisia Santonicum, and Artemisia Spicigera Essential Oils. J Agric Food Chem 53(24): 9452-9458.

19. Ribnicky DM, Poulev A, Watford M, Cefalu WT, Raskin I (2005) Antihyperglycemic Activity of Tarralin, an Ethanolic Extract of Artemisia Dracunculus L. Phytomedicine 13(8): 550-557.

20. Zargari A (1990) Herbal Medicines. $1^{\text {st }}$ (Edn.), Publication of Tehran University, Tehran, pp: 14-18.

21. El Fadl A, Chtaina N (2010) Regional Integrated Pest Management Program in the Middle East. National office for food safety.

22. Hadjlaoui H, Najla T, Emira N, Mejdi S, Hanen F, et al. (2009) Biological activities of the essential oils and methanol extract of tow cultivated mint species (Mentha longifolia and Mentha pulegium) used in the Tunisian folkloric medicine. World Journal of Biotechnology and Microbiology 25: 2227-2238. 